\title{
Kewenangan Dewan Pengawas Syariah Dan Implikasi Terhadap Perwujudan Corporate Social Responsibility Di Perbankan Syariah
}

\author{
Nury Khoiril Jamil ${ }^{1}$, Robiatul Adawiyah ${ }^{2}$, Rumawi $^{{ }^{3 *}}$ \\ 1,2, ${ }^{3}$ Fakultas Syariah Universitas Islam Negeri KH Achmad Siddiq, Jember, Indonesia \\ *E-mail: rumawi@uinkhas.ac.id
}

Dikirim: 16/04/2021

\begin{tabular}{l}
\hline Info Artikel \\
\hline Keywords: \\
Corporate Social \\
Rresponsibilty, \\
Islamic Banking, \\
DPS.
\end{tabular}

Direvisi: 20/10/2021

Dipublikasi: 31/12/2021

Check for updates

\section{Kata Kunci: \\ Corporate Social \\ Responsibility; \\ Perbankan Syariah; \\ DPS.}

DOI:

10.47268/sasi.v27i4.536

\begin{abstract}
Every company has a social responsibility. There are measurements of social responsibility that are carried out to achieve usefulness, one of which is Islamic banking. Although Islamic banking is only considered a labeling issue. However, with the role of DPS which is realized through CSR, it indicates that Islamic banking contributes and is responsible for various social aspects and nation building as a common goal as stated in the 5th principle of Pancasila. This study aims to determine the authority of the Sharia Supervisory Board (DPS) as mandated in laws and regulations and the implications for the realization of Corporate Social Responsibility (CSR) in Islamic banking. This research method is normative juridical, with a statutory and conceptual approach that refers to legal doctrines. The results of the study indicate that DPS has an important role in preventive efforts for activities in Islamic banking as well as the actuality of social responsibility that is realized through CSR.
\end{abstract}

\begin{tabular}{l}
\hline Abstrak \\
Setiap perusahaan memiliki tanggungjawab sosial. Terdapat pengukuran \\
terhadap tanggungjawab sosial yang dilakukan demi tercapainya \\
kebermanfaatan, salah satunya perbankan syariah. Kendati perbankan \\
syariah hanya dianggap persoalan labelisasi. Namun, dengan adanya \\
peran DPS yang diwujudkan melalui CSR, menandakan bahwa perbankan \\
syariah ikut andil dan bertanggungjawab terhadap berbagai aspek sosial dan \\
pembangunan bangsa sebagai cita-cita bersama sebagaimana telah tertuang \\
dalam sila ke-5 Pancasila. Penelitian ini bertujuan untuk mengetahui \\
kewenangan Dewan Pengawas Syariah (DPS) yang diamanatkan dalam \\
peraturan perundang-undangan dan implikasi terhadap perwujudan \\
Corporate Social Responsibility(CSR) di perbankan syariah. Metode \\
penelitian ini adalah yuridis normatif, dengan pendekatan peraturan \\
perundangan-undangan dan pendekatan konsep yang merujuk doktrin- \\
doktrin hukum. Hasil penelitian menunjukkan bahwa DPS memiliki peran \\
penting dalam upaya preventif atas aktivitas di perbankan syariah serta \\
aktualitas terhadap tanggungjawab sosial yang diwujudkan melalui CSR.
\end{tabular}

\section{A. PENDAHULUAN}

Keberadaan Dewan Pengawas Syariah (DPS) memiliki tujuan agar lembaga keuangan

$$
\text { 504|SASI Vo1. } 27 \text { No.4, Oktober - Desember } 2021
$$


syariah dapat menegakkan prinsip syariah dengan baik dan terkontrol, terkhusus dalam bidang perbankan syariah. Adanya DPS adalah hal menjadi pembeda antara perbankan syariah dengan konvensional. DPS bersifat independen serta memiliki kedudukan yang sepadan dengan Dewan Komisaris. Fungsi pengawasan DPS di perbankan syariah dilakukan sejak produk perbankan syariah tersebut akandilaksanakan hingga akad terhadap produk tersebut selesai. Fungsi tersebut bermanfaat sebagai upaya preventif terhadap penyelewengan yang kerap terjadi pada saat akad dilaksanakan, baik dari para pihak yang berakad maupun dari pelaksanaan substansi akad. ${ }^{1}$

Bank Indonesia sebagai otoritas perbankan di tanah air telah menetapkan perbankan syariah sebagai salah satu pilar penyangga dual-banking system, dan mendorong pangsa pasar bank-bank syariah ${ }^{2}$, terdapat tiga fungsi paling esensial dalam bank syariah, yaitu menghimpun dana dari masyarakat dalam bentuk deposito dan investasi, distribusi dana kepada masyarakat yang memerlukan anggaran dari bank; serta menfasilitasi dalam bentuk service terhadap perbankan syariah. ${ }^{3}$ Dalam melaksanakan aktivitas tersebut, perbankan syariah perlu diawasi sebagai upaya preventif penyelenggaran kegiatan perbankan. DPS hadir terlebih dahulu daripada Dewan Syariah Nasional (DSN) yang inisiator awalnya adalah bank syariah secara mandiri.

Todorovic mengatakan bahwa, adanya sistem Good Corporate Governance (GCG) dapat meminimalisir bahkan mencegah skandal di perusahaan perusahaan, fraud, dan potensi tanggungjawab perdata serta pidana terhadap perusahaan. Resiko di perbankan syariah dapat dikatakan lebih kompleks dibanding perbankan konvensional dengan alasan beberapa hal yaitu, fiduciary money, fluktuasi suku bunga, piutang gagal bayar, kesalahan operasional dan sebab lain. Selain itu dalam perbankan syariah, juga menuntut para pelaku bisnis keuangan syariah lebih prudensial termasuk di dalamnya pengawasan dan kontrol yang berfungsi baik. Dengan landasan tersebut, perlunya upaya serius guna peningkatan penyelenggaraan GCG dalam lembaga Perbankan Syariah, ${ }^{4}$ dalam GCG terdapat salah satu prinsip yang berbeda dengan prinsip lainnya. Prinsip tersebut dikenal dengan istilah Corporate Social Responsibility atau singkatnya CSR. CSR dalam prinsip GCG diilustrasikan dua sisi mata uang. Keduanya memiliki peran penting dan tidak terpisahkan satu dengan yang lain. Salah satu dari empat prinsip GCG yang berbeda adalah prinsip responsibility. Sedangkan tiga prinsip lain yaitu fairness, transparency, dan accountability. CSR berfokus pada penekanan terhadap stakeholder guna tercapainya tanggungjawab sosial lembaga terhadap masyarakat.

Pada mulanya pelaksanaan CSR di lembaga atau perusahaanbersifat pengungkapan yang sukarela, namun karena banyak pertimbanganyang membuahkan manfaat, maka CSR berubah menjadi sebuah kewajiban untuk dilaksanakan sesuai dengan amanat UU PT, UU Penanaman Modal dan aturan lainnya. CSR di perbankan syariah khususnya diatur dalam Undang-Undang Nomor 21 tahun 2008 tentang Perbankan Syariah. ${ }^{5}$

Penelitian ini berupaya menghasilkan beberapa kontribusi terhadap kajian hukum di

1 Witasari, A. (2016). "Perspektif Teori Kewenangan Dewan Pengawas Syariah (Dps) Dalam Rangka Penegakkan Prinsip-Prinsip Syariah Pada Lembaga Perbankan Syariah". Jurnal Pembaharuan Hukum, 3(1): http://dx.doi.org/10.26532/jph.v3i1.1340, h.17

2 Labetubun, M. A. H. (2012). Kompetensi Pengadilan Agama Terhadap Penyelesaian Sengketa Perbankan Syariah Berdasarkan Hukum Islam. Sasi, 18(1), 56-62.

3 Pertiwi, D. (2019). "Peran Dewan Pengawas Syariah (DPS) dalam Mewujudkan Good Corporate Governance di Bank Syariah". Jurnal BAABU AL-ILMI: Ekonomi Dan Perbankan Syariah, 4(1), 1. https://doi.org/10.29300/ba.v4i1.1626, h.2

4 Ardana, Y. (2019). "Implementasi Good Corporate Governance (GCG) dalam Mengukur Risiko dan Kinerja Keuangan Bank Syariah di Indonesia". Jurnal Masharif Al-Syariah: Jurnal Ekonomi Dan Perbankan Syariah, 4(1). https://doi.org/10.30651/jms.v4i1.2587, h.99

5 Rahayu, R. S., \& Cahyati, A. D. (2014). "Faktor-Faktor Yang Mempengaruhi Pengungkapan Corporate Social Responsibility (Csr) Pada Perbankan Syariah". JRAK: Jurnal Riset Akuntansi \& Komputerisasi Akuntansi, 5(2). https://doi.org/https://doi.org/10.33558/jrak.v5i2.1346, h.75

505|SASI Vol. 27 No.4, Oktober - Desember 2021 
bidang perbankan syariah. Kontribusi kajian ini yaitu penggunaankajian normatif untuk mengetahui kewenangan DPS dalam menjalankan tugas pengawasan dan efektivitasnya dalam pelanggaran. Implikasi dari kewenangan yang dimiliki DPS akan membuat pembaca mengetahui apakah DPS dapat menjadi sumbangsih terhadap peningkatan positif terhadap laju CSR di perbankan syariah.

Penelitian yang membahas tentang Dewan Pengawas Syariah dan Corporate Social Responsibitily di perbankan syariah sudah pernah dilakukan oleh para peneliti sebelumnya. Hal ini sesuai dengan penelusuran yang dilakukan dengan cara melihat dari beberapa literatur yang ada, maka setidaknya ditemukan dua literatur yang erat kaitannya dengan permasalahan yang ada dalam penelitian ini, yaitu: pertama, Dini Dewindaru, Samsubar Saleh, dan Rifqi Muhammad dengan judul "Karakteristik Dewan Pengawas Sebagai Determinan Kinerja Sosial Bank Syariah"6 dan kedua, Febty Nurhikmah, Winarsih, dan Metta Kusumaningtyasdengan judul "Pengaruh Dewan Pengawas Syariah Dan Intellectual Capital Terhadap Pengungkapan Corporate Social Responsibility Dengan Kinerja Keuangan Sebagai Variabel Mediasi (Studi Empiris Perbankan Syariah Di Indonesia)".?

Penelitian ini menguraikan analisis terhadap: pertama, kewenangan DPS dalam perbankan syariah; kedua, pengaturan Corporate Social Responsibilty dalam Perbankan Syariah; dan ketiga, peran DPS terhadap perwujudan CSR di perbankan syariah. Berdasarkan isu hukum dalam penelitian ini dan telah dilakukan perbandingan dengan melakukan penelitian terdahulu sehingga penelitian mempunyai perbedaan dengan dua penelitian sebelumnya. Halhal yang membedakan di antaranya bisa dilihat bahwa dalam penelitian terdahulu artikel pertama membahas tentang tidak adanya pengaruh positif terhadap pengungkapan CSR bank syariah di Indonesia oleh Dewan Pengawas Syariah (DPS) dan Intellectual Capital (IC). Kinerja keuangan bank syariah di Indonesia bepengaruh positif terhadap pengungkapan CSR. Sedangkan, tidak ada pengaruh yang signifikan terhadap kinerja keuangan bank syariah walaupun Dewan Pengawas Syariah (DPS) dan Intellectual Capital (IC) berpengaruh positif terhadap kinerjanya. Pada artikel kedua membahas mengenai pengukuran terhadap efektivitas kinerja DPS BUS nasional guna mendapat penilaian terhadap kelayakan serta tanggung jawab sosial yang dilakukan oleh bank syariah dengan menggunakan indikator penilaian yang menghasilkan outputberupa data predikat DPS dalam perbankan syariah.

Berdasarkan uraian yang tertuang dalam latar belakang diatas dirumuskan permasalahan dalam penelitian ini sebagai berikut: pertama, bagaimana kewenangan DPS dalam perbankan syariah? kedua, bagaimana pengaturan corporate social responsibility dalam perbankan syariah; dan ketiga, bagaimana peran DPS dalam mewujudkan CSR di perbankan syariah? penelitian ini bertujuan untuk menganalisis: pertama, kewenangan DPS di bank syariah sesuai dengan regulasi yang telah dilegalisasi. Kedua, pengaturan CSR yang terdapat dan digunakan oleh bank syariah, dan ketiga, peran DPS sesuai regulasi terhadap perwujudan CSR di bank syariah.

\section{B. METODE PENELITIAN}

Tipe penelitian dalam penulisan ini adalah penelitian kualitatif dengan metode yuridis normatif. Penelitian hukum dengan pendekatan yuridis normatif atau disebut juga penelitian doktrinal yang melihat tujuan hukum, nilai-nilai keadilan, analisis aturan hukum, konsepkonsep hukum dan norma-norma hukum serta memberikan prekripsi apa yang seyogyanya. ${ }^{8}$

6 Dewindaru, D., Saleh, S., \& Muhammad, R. (2019). "Karakteristik Dewan Pengawas Sebagai

Determinan Kinerja Sosial Bank Syariah". Jurnal Akuntansi Multiparadigma, 10(3). https://doi.org/10.21776/ub.jamal.2019.10.3.27, h.478-479

7 Nurhikmah, F., Winarsih, W., \& Kusumaningtyas, M. (2018). "Pengaruh Dewan Pengawas Syariah dan Intelectual Capital Terhadap Pengungkapan Corporate Social Responsibility dengan Kinerja Keuangan Sebagai Variabel Mediasi (Studi Empiris Perbankan Syariah di Indonesia)". MALIA: Journal of Islamic Banking and Finance, 2(2), 174. https://doi.org/10.21043/malia.v2i2.4785, h.184-185

${ }^{8}$ Marzuki, P. M. (2016). Penelitian Hukum. Jakarta : Kencana Prenadamedia Group. h.141 506|SASI Vo1. 27 No.4, Oktober - Desember 2021 
Penelitian ini menggunakan pendekatan undang-undang (statute approach), yaitu pendekatan ini dilakukan dengan mengkaji suatu peraturan perundang-undangan, dan pendekatan konsep (conceptual approach) yang merujuk pada prinsip-prinsip hukum yang dikemukakan oleh para sarjana hukum ataupun doktrin-doktrin hukum. ${ }^{9}$ Sumber-sumber hukum yang digunakan dalam penelitian ada dua yaitu: 1). Bahan hukum primer yaitu bahan hukum yang bersifat autoritatif yang artinya mempunyai otoritas terdiri atas peraturan perundangan-undangan, meliputi: Pasal 32 Undang-Undang Nomor 21 Tahun 2008 tentang Perbankan Syariah dan Peraturan Perbankan Indonesia Nomor 11/33/PBI/2009 tentang Pelaksanaan Good Corporate Governance bagi Bank Umum Syariah dan Unit Usaha Syariah. 2). Bahan hukum sekunder yaitu bahan hukum yang berupa publikasi hukum yang bukan merupakan dokumen resmi. Publikasi tentang hukum yang meliputi: buku-buku teks, kamus-kamus hukum, jurnal-jurnal hukum, dan komentar-komentar atas putusan pengadilan. ${ }^{10}$ Metode pengumpulan bahan hukum terdiri atas: 1). Studi peraturan perundang-undangan merupakan suatu upaya untuk menelaah dan memahami peraturan perundang-undangan yang mengatur mengenai rumusan masalah dalam penelitian ini. 2). Studi kepustakaan, digunakan untuk mencari konsepsi, teori, dan pendapat yang berkaitan dengan rumusan masalah dalam penelitian ini. ${ }^{11}$ Kesimpulan didasarkan pada analisis pokok masalah yang dijadikan preskripsi.

\section{PEMBAHASAN}

\section{Kewenangan DPS dalam Perbankan Syariah}

Lembaga yang bertugas dan berwenang dalam memberikan solusi atas problematika keagamaan Islam di Indonesia serta bertanggungjawab atas pengawasan lembaga-lembaga keuangan syariah di Indonesia agar sesuai dengan prinsip syariah adalah MUI (Majelis Ulama Indonesia). Munculnya Dewan Pengawas Syariah (DPS) di berbagai lembaga keuangan syariah yang dibentuk secara mandiri, membuat MUI mengambil sikap dengan turut membentuk dewan pengawas syariah yang bersifat nasional. Mengingat bahwa MUI adalah pengayom dari lembaga dan organisasi Islam yang ada di Indonesia, ${ }^{12}$ dalam rangka mensosialisasikan ide tersebut, tepatnya bulan Juli 1997 pada acara lokakarya Reksadana Syariah menghasilkan rekomendasi pembentukan Dewan Syariah Nasional (DSN).Berjarak satu tahun, pada tahun 1998 DSN dibentuk oleh MUI. ${ }^{13}$ Guna memperkuat legitimasi dan legalisasi, maka DSN dikukuhkan pada tanggal 10 Februari 1999 melalui SK Dewan Pimpinan MUI Nomor Kep754/MUI/II/1999.Dengan turunnya SK tersebut, maka terbentuk anggota DSN memiliki anggota berjumlah 16 orang yang pada waktu itu dipimpin oleh Prof. K.H. Ali Yafie sebagai ketua dan BPH dipimpin oleh K.H. Ma'ruf Amin sebagai ketua. Seiring dengan perkembangan dan kebutuhan mengharuskan keanggotaan DSN untuk ditambah. Tercatat pada tahun 2003 anggota DSN berjumlah 34 orang dan BPH DSN berjumlah 13 orang, yaitu berdasarkan SK Dewan Pimpinan MUI Nomor Kep-200/MUI/VI/2003. Anggota tersebut berlatarbelakang dari tokoh-tokoh akademisi, ulama serta ekonom.

Dewan Pengawas Syariah (DPS) merupakan badan memiliki tugas dan wewenang untuk mengawasi pelaksanaan atau kegiatan atas keputusan Dewan Syariah Nasional (DSN) di lembaga keuangan syariah.Rekomendasi dari DSN MUI menjadi faktor yang krusial dalam pengangkatan atau pemberhentianDPS di perbankan syariah melalui Rapat Umum Pemegang Saham (RUPS). ${ }^{14}$ Menyelisik pada surat keputusan Dewan Syariah Nasional Nomor 3 Tahun 2000, bahwa Dewan Pengawas Syariah (DPS) adalah lembaga yang penempatannya atas

\footnotetext{
9 Ibid. h. 138-139

10 Ibid. h. 141

11 Ibid. h. 171

12 Indonesia, T. P. P. S. I. B. (2002). Konsep, Produk dan Implementasi Operasional Bank Syari'ah. Jakarta : Djambatan. h.28

13 Hasanudin. (2002). Fungsi, Peran dan Mekanisme Kerja Dewan Syari'ah Nasional MUI. p.22

14 Firdaus, M. (2007). Sistem dan Mekanisme Pengawasan Syariah. Jakarta: Renaisan. h.16
} 507|S A S Vo1. 27 No.4, Oktober - Desember 2021 
persetujuan Dewan Syariah Nasional (DSN) yang bagian dari Lembaga Keuangan syariah dan bertugas mengawasi pelaksanaan keputusan DSN

Tugas DPS adalah membahas masalah serta transaksi usaha yang diajukan kepadanya. Kemudian, menetapkan keputusan tentang transaksi atau masalah tentang kesesuaiannya dengan syariah. Selanjutnya, wewenang DPS adalah: (a) memberikan dasar hukum syariah kepada bank untuk kegiatan lembaga, pengerahan dana, dan kegiatan bank lainnya; dan (b) mengevaluasi serta membenahi suatu produk yang terindikasi dan terbukti dijalankan tidak sesuai syariah. ${ }^{15}$ Fungsi Dewan Pengawas Syariah antara lain: ${ }^{16}$

1) Mengawasi lembaga keuangan syariah yang berada di bawah pegawasanya secara berkala.

2) Wajib mengajukan saran kepada pimpinan lembaga dan kepada DSN untuk kemajuan lembaga keuangan syariah.

3) Melakukan laporan pada lembaga keuangan syariah yang berada di bawah pengawasanya kepada DSN minimal dua kali dalam setahun mengenai perkembangan produk dan operasional LKS.

4) DPS merumuskan persoalan yang memerlukan pembahasan dengan DSN.

Sebagaimana tertera dalam Pedoman Dasar DSN, sistem kerja DPS adalah sebagai berikut:

1) Melakukan pengawasan secara periodik pada lembaga keuangan syari'ah yang berada di bawah pengawasannya.

2) Berkewajiban mengajukan usul-usul pengembangan lembaga keuangan syari' ah kepada pimpinan lembaga yang bersangkutan dan kepada Dewan Syari'ah Nasional.

3) Melaporkan perkembangan produk dan operasional lembaga keuangan syari'ah yang diawasinya kepada DSN sekurang-kurangnya dua kali dalam satu tahun anggaran.

4) Merumuskan permasalahan-permasalahan yang memerlukan pembahasan DSN.

Menurut pasal 32 ayat (3) Undang-Undang Nomor 21 Tahun 2008 tentang Perbankan Syariah mengatakan bahwa "Dewan Pengawas Syariah sebagaimana dimaksud pada ayat (1) bertugas memberikan nasihat dan saran kepada direksi serta mengawasi kegiatan bank agar sesuai dengan prinsip syariah.” Tugas dan tanggungjawab Dewan Pengawas Syariah tercantum dalam Pasal 46 Peraturan Bank Indonesia Nomor 11/33/PBI/2009 tentang Pelaksanaan Good Corporate Governance bagi Bank Umum Syariah dan Unit Usaha Syariah yakni wajib menjalankan tugas dan tanggung jawab yang sependirian dengan prinsip-prinsip GCG. Hal ini kemudian lebih diperjelas dalam Pasal 47: ${ }^{17}$

1) DPS bertugas mengawasi kegiatan Bank agar sesuai dengan Prinsip Syariah dan menyampaikan nasihat atau saran kepada Direksi.

2) DPS melaksanakan tugas dan tanggung jawab antara lain:

a) Memastikan dan memenuhi pedoman operasional dan produk yang dikeluarkan Bank telah sesuai dengan prinsip syariah.

b) Meninjauproses pengembangan produk baru Bank agar sesuai dengan fatwa Dewan Syariah Nasional - Majelis Ulama Indonesia (DSN-MUI);

c) Meminta fatwa untuk produk baru Bank yang belum memiliki fatwa kepada DSNMUI

d) Mengulas secara berkala mekanisme penghimpunan dana dan penyaluran dana serta pelayanan jasa Bank untuk pemenuhan Prinsip Syariah; dan

15 Perwataatmadja, K., \& Antonio, M. S. (1992). Apa dan Bagaimana Bank Islam. Yogyakarta: Dana Bhakti Wakaf. h. 2

16 Firdaus, M. (2005). Briefcase Book Eduksi Profesional Syariah. Jakarta : Renaisan. h.17

17 Peraturan Bank Indonesia Nomor 11/33/PBI/2009 tentang Pelaksanaan Good Corporate Governance bagi Bank Umum Syariah dan Unit Usaha Syariah. (n.d.).

508|S A S V Vol. 27 No.4, Oktober - Desember 2021 
e) Melaksanakan tugas dengan meminta data serta informasi mengenai aspek syariah dari satuan kerja Bank

3) Secara semesteran DPS wajib menyampaikan Laporan Hasil Pengawasan DPS.

4) Laporan Hasil Pengawasan DPS wajib disampaikan kepada Bank Indonesia paling lambat 2 bulan setelah semesteran berakhir.

5) Pelaksanaan tugas dan tanggung jawab akan diatur lebih rinci dalam Surat Edaran Bank Indonesia.

\section{Pengaturan Corporate Social Responsibilty dalam Perbankan Syariah}

Corporate Social Responsibility (CSR) dalam prinsip Good Corporate Governance (GCG) diilustrasikan dua sisi mata uang. Keduanya memiliki peran penting dan tidak terpisahkan satu sama lain. Salah satu dari empat prinsip GCG yang berbeda adalah prinsip responsibility. Sedangkan tiga prinsip lain yaitu fairness, transparency, dan accountability.Perbedaan mendasar antara prinsip responsibility dengan tiga prinsip GCG lainnya yakni tiga prinsip GCG memberi penekanan terhadap kepentingan pemegang saham perusahaan (shareholders), sedangkan CSR berfokus pada penekanan terhadap stakeholder guna tercapainya tanggung jawab sosial lembaga terhadap masyarakat, ${ }^{18}$ dalam gagasan CSR, tanggungjawab perusahaan harus berpijak pada triple bottom lines ${ }^{19}$ yaitu memperhatikan masalah sosial dan lingkungan karena kondisi keuangan tidak cukup menjamin nilai perusahaan tumbuh secara berkelanjutan (sustainable). Dewasa ini, perusahaan tidak hanya dihadapkan pada tanggungjawab yang berpijak pada single bottom line, yaitu nilai perusahaan (corporate value) yang direfleksikan dalam kondisi keuangannya saja. ${ }^{20}$ Keberlanjutan perusahaan hanya akan terjamin apabila perusahaan memperhatikan dimensi sosial dan lingkungan hidup.

Terdapat cara untuk perusahaan khususnya bank syariah untuk mendapatkan nilai tambah (add value) yaitu dengan adanya aktivitas-aktivitas sosial. Cara demikian dapat meningkatkan kepercayaan stakeholder terhadap kinerja bank syariah, juga meningkatkan profitabilitas jangka panjang dan goodwill yang didapat dari citra positif dari bisnis yang dijalankan. ${ }^{21}$ Mewujudkan keyakinan para stakeholder adalah tantangan utama bank syariah saat ini. Dengan membangun trust stakeholder, bank syariahberpeluang dan diharapkan mampu memobilisasi simpanan, menarik investasi, menyalurkan pembiayaan, bahkan memperluas kesempatan kerja, serta membantu pemerintah membiayai defisit anggaran untuk pembangunan, dan mengakselerasi pembangunan ekonomi dengan baik. ${ }^{22}$ Pemerintah Indonesia secara istimewa mendorong peran serta perusahaan-perusahaan untuk melakukan kegiatan CSR. Pengaturan mengenai hal tersebut terkandung dalam pasal 74 Undang-Undang Nomor 40 tahun 2007 tentang Perseroan Terbatas, yang dinyatakan sebagai berikut:

1) Perseroan wajib melaksanakan Tanggung Jawab Sosial dan Lingkungan jika menjalankan kegiatan usaha di bidang yang berkaitan dengan sumber daya alam

2) Kewajiban tersebut harus dilakukan dengan memperhatikan kepatutan dan kewajaran serta harus dianggarkan dan diperhitungkan sebagai biaya Perseroan.

3) Apabila Perseroan yang tidak melaksanakan kewajiban sesuai dengan ketentuan peraturan perundang-undangan akan dikenai sanksi

18 Wibowo, M. G. (2007). Potret Perbankan Syariah Terkini: Kajian Kritis Perkembangan Perbankan Syariah Terkini. Yogyakarta : Biruni Press. h.136

${ }^{19}$ Sinergi tiga elemen yang meliputi ekonomi, sosial, dan lingkungan atau lebih dikenal dengan 3P (Profit, People dan Planet).

20 Iskandar, I. (2016). "Pengaruh Penerapan Corporate Social Responsibility Terhadap Profitabilitas Perusahaan". FORUM EKONOMI: Jurnal Ekonomi, Manajemen Dan Akuntansi, 18(1). https://doi.org/http://dx.doi.org/10.29264/jfor.v18i1.48 h.76

21 Wibowo, M. G. (2007). Op. Cit. h.136

22 Setiawan, A. B. (2009). Kesehatan Finansial dan Kinerja Sosial Bank Umum Syariah di Indonesia. Universitas Paramadina. h.1

$$
\text { 509|SASI Vo1. } 27 \text { No.4, Oktober-Desember } 2021
$$


4) Peraturan Pemerintah akan mengatur lebih lanjut mengenai Tanggung Jawab Sosial dan Lingkungan.

Pengaturan lain yang juga mengatur mengenai CSR adalah Pasal 15(b) dan Pasal 16 (d)Undang-Undang Nomor 25 tahun 2007tentang Penanaman Modal. ${ }^{23}$ Hal sepadanjuga berlaku bagi entitas perbankan syariah yang tertuang UU Perbankan Syariah harus berbentuk perseroan terbatas, maka perbankan syariah harus melaksanakan aktivitas CSR-nya.

Pasal 34 Undang-Undang Nomor 21 tahun 2008 tentang Perbankan Syariah diatur khusus mengenai Pelaksanaan GGC Perbankan Syariah ${ }^{24}$ yakni kewajiban bank syariah dan UUS dalam menerapkan serta menysun prosedur internal mengenai tata kelola yang baik dalam menjalankan kegiatan usahanya yang terdiri dari prinsip akuntabilitas, transparansi, profesional, pertanggungjawaban dan kewajaran. Ketentuan mengenai tata kelola yang baik diatur lebih lanjut dalam Peraturan Bank Indonesia Nomor 11/33/PBI/2009 tentang Pelaksanaan GCG bagi Bank Umum Syariah dan Unit Usaha Syariah. Dalam Pengaturan tersebut juga dilengkapi oleh Komite Nasional Kebijakan Governance (KNKG) dengan Pedoman GCG Perbankan Indonesia tahun 2004 dan Pedoman Good Governance Bisnis Syariah (GGBS) tahun 2011. Dengan demikian, dapat dikatakan implementasi Good Corporate Governance (GCG) khususnya dalam aspek Corporate Social Responsibility di lembaga perbankan syariah adalah sebuah keniscayaan yang tak terbantahkan.

\section{Peran DPS terhadap perwujudan CSR di Perbankan Syariah}

Suatu pola tingkah laku, nilai, dan sasaran baik pribadi maupun tanggungjawab adalah merupakan sebuah peran. Posisi ini merupakan rekognisi dari status, posisi atau tempat seseorang dalam suatu social system dan sebagai aksi dalam rangka aktualisasi diri. Dalam Kamus Besar Bahasa Indonesia, peran adalah perangkat tingkah yang diharapkan dimiliki oleh seseorang yang berkedudukan dalam masyarakat. ${ }^{25}$ AAOIFI $^{26}$ dalam Governance Standard for Islamic Finacial Institutions (GSIFI) menjelaskan bahwa peran DPS adalah directing, reviewing and supervising the activities of Islamic Financial Institution in orderto ensure that they are in compliance with Islamic shari'a rules and principles.Artinya, peran yang dimiliki DPSyakni mengarahkan, menilai,dan mengawasi seluruh aktivitas institusi keuangan Islam yang bertujuan guna memastikan pekerjaannya sesuai prinsip dan aturan syariah. Berdasar pada hal tersebut setidaknya menurut AAOIFI ada tiga peran utama DPS di lembaga keuangan syariah, yaitu menyesuaikan aktivitas bank syariah agar sependirian dengan aturan dan prinsip syariah dengan melakukan penilaian, pengarahan dan pengawasan. Kecuali tiga peran di atas, terdapat satu peran DPS yang ditambahkan oleh DSN-MUI, yakni melakukan sosialisasi dan edukasi kepada masyarakat tentang bank syariah melalui media-media yang sudah berjalan di masyarakat, seperti khutbah, majelis ta'lim, serta pengajian-pengajian. ${ }^{27}$

Memandang pada peran DPS menurut AAOIFI dan DSN-MUI, makaperan DPS dalam implementasi prinsip-prinsip GCG di bank syariah antara lain:

1) Directing yaitu memberikan petunjuk, saran dan usul kepada direksi bank syariah berkaitan dengan hal-hal aspek syariah dalam perbankan.

23 Syukron, A. (2015). "CSR dalam Perspektif Islam dan Perbankan Syariah". Economic: Jurnal Ekonomi Dan Hukum Islam, 5(1), 1-22. h.2

24 Undang-Undang Nomor 21 tahun 2008 tentang Perbankan Syariah. (n.d.).

25 Indonesia, B. P. dan P. B. K. P. dan K. R. (2016). Kamus Besar Bahasa Indonesia (KBBI). https://kbbi.kemdikbud.go.id/

26 Accounting and Auditing Organization For Islamic Financial Institutions (AAOIFI) adalah organisasi internasional islam non badan hukum nirlaba yang menyiapkan standar akuntansi, audit, pemerintahan, etika dan standar syariat islam lembaga keuangan dan industri. AAOIFI dibentuk di Bahrain pada 27 Maret 1991.

27 Faozan, A. (2013). "Implementasi Good Corporate Governance Dan Peran Dewan Pengawas Syariah Di Bank Syariah". La_Riba, 7(1), 1-14. https://doi.org/10.20885/lariba.vol7.iss1.art1 h.11

510|SASI Vo1. 27 No.4, Oktober - Desember 2021 
2) Reviewing yaitu mengkaji tentang implementasi fatwa DSN pada operasional bank syariah.

3) Supervisingyaitu melakukan tugas berupa pengawasan pada implementasi fatwa DSN pada operasional bank syariahbaik secara aktif maupun secara pasif.

4) Marketing yaitu menyelenggarakan sosialisasi kepada masyarakat melalui media yang dekat dengan masyarakat untuk lebih mengenalkan tentang bank syariah.

Jika dibandingkan dengan Malaysia dalam pelaksanaan dan penerapan CSR khususnya dalam perbankan syariah ternyata di Indonesia masih rendah. Hal tersebut diungkap oleh Hafiez Sofyani, Ihyaul Ulum, Daniel Syam, dan Sri Wajuni L bahwa problematika tersebut disebabkan oleh keterbatasan program yang tepat sasaran dalam menyalurkan CSR. Sedangkan sistem di Malaysia, pelaksanaan dan penerapan CSR dilakukan melalui sub-item Customer Complaint, Employee Involvement, Waqaf, Scholarship, Youth Development, Children Care, Polution, dan Education yang artinya Pengaduan, Keterlibatan Karyawan, Wakaf, Beasiswa, Pembinaan Remaja, Perawatan Anak, Polusi, dan Pendidikan ${ }^{28}$ CSR dianggap sebagai sentra biaya (cost centre) sehingga berpotensi mengurangi laba perusahaan adalah satu hal sebab lemahnya pelaksanaan CSR di Indonesia. Persaingan perbankan yang kompetitif dan orientasi maksimal profit menjadi penyumbang sebab bank Syariah cenderung melayani kelompok kuat dan profitable. Hal tersebut menjadikan belum optimalnya Bank Syariah dalam melaksanakanfungsi sosial yakni memfasilitasi koherensi antara voluntary sector dengan pemberdayaan ekonomi marjinal. ${ }^{29}$

Sistem operasional bank syariah wajib dijalankan sependirian dengan ketentuan perbankan syariah yang berlaku. Dalam aktivitas perbankan syariah telah diterapkan penjaminan prinsip syariah dengan salah satu pihak terafiliasi yaitu Dewan Pengawas Syariah atau singkatnya DPS sebagai pemberi jasa kepada bank syariah. Dalam rangka memastikan bahwa kegiatan usaha bank syariah tersebut mematuhi (compliance) terhadap prinsip syariah sebagaimana telah ditentukan oleh fatwa dan syariah Islam, DPS bertugas melakukan evaluasi (evaluating), pengarahan (directing), pemberian konsultasi (consulting), dan pengawasan (supervising) kegiatan bank syariah. ${ }^{30}$

Dalam teori agen, dengan menyelenggarakan pengawasanakan terhindar dari kemungkinan timbulnya konflik agensi. Operasional bank syariah harus sesuai dengan prinsip syariah dengan pengawasan dari DPS.Kuantitas anggota DPS berimplikasi pada kinerja yang lebih cakap karena dewan lebih memiliki pengalaman, keahlian, dan jaringan profesional serta sosial yang baik. Kemudian, pengawasan juga akan lebih baik sejalan tingkat kepatuhan syariah menjadi lebih baik sehingga dapat menurunkan masalah agensi yang diselenggarakan oleh pihak manajemen bank syariah. ${ }^{31}$

Hukum yang baik yakni hukum responsive harus memberikan sesuatu yang lebih dari prosedur hukum dengan berkompeten dan adil, mampu mengenali keinginan publik dan memiliki komitmen terhadap tercapainya keadilan substantif. ${ }^{32}$ Hukum responsif berada pada posisi untuk mengatasi dua pertimbangan antara integritas dan keterbukaan. Faktanya, perusahaan yang menjalankan CSR dalam kegiatan usahanya berdampak positif terhadap saham di bursa efek. Dengan alasan tersebut, semula CSR adalah tanggung jawab non-hukum (responsibility) diubah menjadi tanggungjawab hukum (liability) yang harus dimaknai sebagai

28 Nofrianto, N., \& Suardi, S. (2015). "Bank Syariah Dan Pemberdayaan Coorporate Social Responsibility". AKADEMIKA: Jurnal Pemikiran Islam; Vol 20 No 2 (2015): Islam Dan Kesejahteraan Sosial. https://ejournal.metrouniv.ac.id/index.php/akademika/article/view/446, h.262-263

29 Ibid.

30 Zuliana, R., \& Aliamin, A. (2019). "Pengaruh Dewan Pengawas Syariah, Intellectual Capital, Dan Corporate Social Responsibility Terhadap Kinerja Bank Syariah Di Indonesia". Jurnal Ilmiah Mahasiswa Ekonomi Akuntansi, 4(4), 677-693. https://doi.org/10.24815/jimeka.v4i4.15335, h.681

31 Ibid, h.682

32 Nonet, \& Selznick. (2003). Hukum Responsif. Bandung : Nusa Media. h.60 511|SASI Vo1. 27 No.4, Oktober - Desember 2021 
instrumen untuk menjadi praktik bisnis yang etis kebermanfaatan.

Berhubungan dengan praktik CSR yang ada di Indonesia pengusaha dapat dibedakan menjadi 4 bagian yaitu: ${ }^{33}$ hitam, merah, biru, dan hijau. Hitam berarti perusahaan tersebut pengusahanya tidak mengimplementasikan CSR. Merah berarti perusahaan yang menjalankan CSR, tetapi sekedar dipandang sebagai unsur biaya yang mengurangi laba dan dilaksanakan karena tekanan atau kewajiban. Biru memiliki arti perusahaan yang menganggap bahwa praktik CSR akan melimpahkan dampak positif terhadap usahanya karena merupakan investasi, bukan biaya. Hijau berarti perusahaan yang memposisikan CSR pada jantung bisnisnya, sehingga CSR tidak dianggap sebagai keharusan tetapi kebutuhan. ${ }^{34}$

Bank Syariah sebagai lembaga keuangan yang bertujuan terhadap kejayaan stakeholders dan shareholders secara berbarengan, hal inimerupakan landasan filosofi bagi perusahaan untuk menerapkan environmental ethics dengan berpatokan tidak hanya berkehendak pada pelayanan dalam bentuk mendapat keuntungan (profit margin) dari aktivitas bisnis dengan konsumen, tetapi juga memenuhi kebutuhan lingkungan (society, stakeholders) dan tanggung jawab terhadap pemerintah dalam menjalankan peraturan perundang-undangan. ${ }^{35}$ Pengembangan Perbankan Syariah di Indonesia memuat visi, misi dan sasaran pengembangan Perbankan syariah serta sekumpulan inisiatif strategis dengan prioritas yang jelas untuk menjawab tantangan utama dan mencapai sasaran dalam kurun waktu 10 (sepuluh) tahun ke depan, yaitu pencapaian pangsa pasar Perbankan syariah yang signifikan melalui pendalaman peran Perbankan syariah dalam aktivitas keuangan nasional, regional dan internasional, dalam kondisi mulai terbentuknya integrasi dengan sektor keuangan syariah lainnya. ${ }^{36}$ Kompetisi persaingan bank Syariah berusaha dalam mengubah paradigma yang selama ini menjadi mainstream kapitalis dalam dunia bisnis (perusahaan) atau mencari keuntungan sebanyakbanyaknya tanpa memerhatikan problem sosial dengan skema dan sistem perusahaan mendapatkanlabauntuk kepentingan pemegang saham (shareholders), melaksanakan bisnis dengan tidak memperhatikan etika dan nilai (materialis), serta abai terhadap norma agama (hedonis).

Salah satu bentuk perilaku ibadah kepada Allah SWT dengan berorientasi kepada ajaran at-tauhid dan memberikan kesadaran yang tinggi pada eksistensi manusia di muka bumi ini sebagai khalifah (khalifah fiil ardh) dalam perspektif bisnis (muamalah al-iqtishady) adalah melaksanakan aktivitas bisnis dan mekanisme kerja pada bank syariah, aktivitas bisnis perbankan syariah merupakan kegiatan yang kelak akan dipertanggungjawabkan kepada Allah swt di hari pembalasan. Hal tersebut jika dikaji dalam kacamata normatif-teologis. ${ }^{37}$ Implementasi CSR di bank syariah adalah konsekuensi logis dan melekat yang terkandung dalam ajaran Islam. Tujuan dari diadakannya syariat Islam (maqashid al-syariah) adalah terciptanya kebermanfaatan. Upaya untuk mencapai tujuan dari maqashid al-syariah yaitu maslahah (kebaikan) di dunia dan akhirat - long term oriented (al-falah) serta life hereafter (alma'ad) dengan bisnis keuangan yang dilaksanakan oleh Bank Syariah. Terdapat enam (6) kriteria CSR di Lembaga Keuangan Syariah (LKS) meliputi: ${ }^{38}$

33 Untung, H. B. (2008). Corporate Social Responsibility. Jakarta : Sinar Grafika. h.8

34 Muskibah, M. (2011). "Tanggung Jawab Sosial Perusahaan dalam Kegiatan Penanaman Modal". Inovatif: Jurnal Ilmu Hukum, 4(5), 155-167. https:/online-journal.unja.ac.id/jimih/article/view/542, h.162

${ }^{35}$ Nofrianto, N., \& Suardi, S. (2015). "Bank Syariah Dan Pemberdayaan Coorporate Social Responsibility". AKADEMIKA: Jurnal Pemikiran Islam; Vol 20 No 2 (2015): Islam Dan Kesejahteraan Sosial. https:/lejournal.metrouniv.ac.id/index.php/akademika/article/view/446, h.269

${ }^{36}$ Labetubun, M. A. H. (2020). Pengaturan Perbankan Syariah Di Indonesia. In Pengantar Perbankan Syariah (pp. 103-117). Bandung: Widina Bhakti Persada Bandung. h. 111.

37 Nofrianto, N., \& Suardi, S. (2015). "Bank Syariah Dan Pemberdayaan Coorporate Social Responsibility". AKADEMIKA: Jurnal Pemikiran Islam; Vol 20 No 2 (2015): Islam Dan Kesejahteraan Sosial. https://ejournal.metrouniv.ac.id/index.php/akademika/article/view/446, h.272

38 Zumaroh, Z., \& Wahyuni, D. (2019). "Problematika Implementatif Corporate Social Responsibility (CSR) Pada Bank Syariah Di Indonesia". JURNAL ILMIAH MIZANI: Wacana Hukum, Ekonomi, Dan Keagamaan, 
1) Kepatuhan Syariah

Kepatuhan syariah adalah perbuatan preventif (ex-ante) guna memastikan terlaksananya segala ketentuan sesuai dengan peraturan yang ada. Baik UU Perbankan Syariah, Peratuan Bank Indonesia, Fatwa DSN MUI, dan peratuan yang berlaku. Hal ini berfungsi untuk controllingoperasional lembaga perbankan syariah dan mengantisapasi bank syariah supaya tidak menjalankan lembaga di luar ketentuan serta menimimalisir resiko.

2) Keadilan dan kesetaraan

Nilai keadilan dalam operasional perbankan syariah adalah nilai tinggi yang dijunjung dalam Islam dalam menservicekepada stakeholder. Prisip persaudaraan (brotherhood) dan keadilan menjadi landasan sebagai wujud komitmen sosial perbankan syariah. Hal itu dapat diukur melalui beberapa kriteria kesamaan dalam operasional Lembaga Keuangan Syariah (LKS) yaitu: 1. hadirnya nilai persaudaraan; 2. kualitas dalam layanan; 3. tidak diskriminasi; dan 4. memiliki kesempatan yang sama.

3) Bertanggungjawab dalam bekerja

Tanggungjawab dalam bekerja terdapat dua kategori, yaitu mikro dan makro. Dalam perspektif mikro semua dana yang diperoleh dalam sistem LKS dikelola dengan integritas tinggi dan sangat berhati-hati mencerminkan sifat-sifat shiddiq (benar), tabligh (menyampaikan), amanah (jujur), dan fathanah (cerdas). Berbeda dengan perspektif makro yang mengharuskan pemberian kesejahteraan masyarakat dengan mengaktifkan zakat dalam memengaruhi supaya suka terhadap investasi daripada menimbun harta. Pelarangan riba dengan opsi mudharabah atau bagi hasil serta mengutamakan kerelaan dalam transaksi dan kegiatan perbakan lain. Terdapat beberapa indikator dalam mencapai kriteria bertanggung jawab, yaitu: amanah, ikhlas, integritas dan akuntabel.

4) Jaminan kesejahteraan

Kepedulian lembaga dalam bentuk tanggungjawab sosial ketika menjalankan operasi di masyarakat dan kelompok yang berada di suatu ruang lingkup. Ukuran jaminan kesejahteraan dalam CSR perbankan syariah yaitu: tempat bekerja efektif, kebebasan berkeinginan, penghasilan yang proporsional, trainingdan pendidikan, jam kerja yangwajar, sertaprofit sharing yang adil.

5) Jaminan kelestarian alam

Dalam menciptakan CSR dalam lingkup kelestarian alam, setiap sikap yang diambil LKS harus dilakukan dalam tiga prinsip yaitu: Pertama, dalam konteks penciptaan alam maka harus menghargai keseimbangan sunnatullah. Kedua, tidak membuat kerusakan dan berpotensi bahaya. Ketiga, ikut menjaga kelestarian alam. Pencapaian tersebut dapat dikukur melalui empat kriteria, yaitu: 1) menjamin pelaksanaan program bank syariah tidak mengacau alam sekitar; 2) aktif menjaga alam sekitar; c) memberikan pemahaman kepada pekerja untuk menjaga dan melestarikan alam sekitar; dan d) menggunakan bahan-bahan ramah lingkungan yang dapat didaur ulang dalam memenuhi keperluan LKS.

6) Bantuan kebajikan atau sosial

Perbakan syariah hadir sebagai solusi finansial di tengah masyarat yang kurang mampu. Maka, terdapat penetapan kriteria dalam pencapaian CSR dalam bidang bantuan sosial. Setidaknya ada lima aspek atau kriteria agar perbankan syariah dapat dikatakan telah memenuhi CSR dalam bidang ini, yaitu: 1) menyeleksi dan memilih lembaga yang satu visi dan misi CSR dengan bank syariah. 2) ikut serta meringankan problem sosial (dapat berbentuk bantuan sosial). 3) mengupayakan dan realisasi program bidang kemasyarakatan (dapat berbentuk beasiswa dan bantuan sejenis). 4) tidak mengorientasikan program CSR sebagai keuntungan lembaga semata. 5) produk LKS 
sebagai pemberdayaan di masyarakat, pembiayaan mikro ekonomi untuk usaha kecil dan menengah (UKM).

Dengan demikian, Dewan Pengawas Syariah (DPS) yang memiliki fungsi pengawasan secara berkala pada lembaga keuangan syariah, mengajukan saran demi pengembangan lembaga keuangan syariah, melaporkan perkembangan produk dan sistem operasional lembaga keuangan syariah, dan meninjau permasalahan yang memerlukan pembahasan DSN. Juga sesuai dengan Pasal 32 ayat (3) jo. (4) Undang-Undang Nomor 21 tahun 2008 tentang Perbankan Syariah serta Peraturan Bank Indonesia Nomor 11/33/PBI/2009 tentang Pelaksanaan Good Corporate Governance bagi Bank Umum Syariah dan Unit Usaha Syariah. Maka kewenangan, tugas pokok dan fungsi yang diamanatkan dalam peraturan perundang-undang dan peraturan terkait DPS dan praktik CSR di Perbankan Syariah dapat terwujuddengan baik dan sesuai dengan harapan Bank Syariah sebagai lembaga keuangan yang bertujuan pada kemaslahatan umat.

\section{P E N U T U P}

Pasal 32 ayat 3 Undang-Undang Nomor 21 Tahun 2008 tentang Perbankan Syariah mengatakan bahwa, DPS mempunyai tugas untukmenasihati dan memberi saran kepada direksi. Selain itu, DPS juga harus memastikan kegiatan bank sesuai dengan prinsip syariah dengan mengawasinya. Tugas dan tanggungjawab Dewan Pengawas Syariah dalam Pasal 46 Peraturan Bank Indonesia Nomor 11/33/PBI/2009 tentang Pelaksanaan Good Corporate Governance bagi Bank Umum Syariah dan Unit Usaha Syariah yaitu wajib melaksanakan tugas dan tanggung jawab sesuai dengan prinsip-prinsip GCG dan diperjelas pada pasal 47 dalam PBI $a$ quo.Perbankan syariah adalah berbentuk PT sesuai dengan UU Perbankan Syariah, maka ketentuan bank syariah mengikuti UU PT, kemudian CSR diatur dalam Pasal 74 UndangUndang Nomor 40 tahun 2007 tentang Perseroan Terbatas mengatur mengenai CSR. Regulasi lain tentang CSR yakni Pasal 15(b) dan Pasal 16 (d) Undang-Undang Nomor 25 tahun 2007 tentang Penanaman Modal.DPS memiliki fungsi pengawasan secara berkala pada lembaga keuangan syariah, mengajukan saran demi pengembangan lembaga keuangan syariah, melaporkan perkembangan produk dan sistem operasional lembaga keuangan syariah, dan meninjau permasalahan yang memerlukan pembahasan DSN. Dengan kewenangan yang dimiliki, maka CSR dapat diwujudkan dengan baik mengingat CSR selaras dengan ajaran Islam mengenai kebermanfaatan.

\section{DAFTAR PUSTAKA}

\section{Jurnal}

[1] Dewindaru, D., Saleh, S., \& Muhammad, R. (2019). Karakteristik Dewan Pengawas Sebagai Determinan Kinerja Sosial Bank Syariah. Jurnal Akuntansi Multiparadigma, 10(3). DOI : 10.21776/ub.jamal.2019.10.3.27

[2] Ardana, Y. (2019). Implementasi Good Corporate Governance (GCG) dalam Mengukur Risiko dan Kinerja Keuangan Bank Syariah di Indonesia. Jurnal Masharif Al-Syariah: Jurnal Ekonomi Dan Perbankan Syariah, 4(1). DOI : 10.30651/jms.v4i1.2587

[3] Faozan, A. (2013). Implementasi Good Corporate Governance Dan Peran Dewan Pengawas Syariah Di Bank Syariah. La_Riba, 7(1), 1-14. DOI : 10.20885/lariba.vol7.iss1.art1

[4] Iskandar, I. (2016). Pengaruh Penerapan Corporate Social Responsibility Terhadap Profitabilitas Perusahaan. Forum EkonomI: Jurnal Ekonomi, Manajemen Dan Akuntansi, 18(1). DOI : 10.29264 jfor.v18i1.48

[5] Labetubun, M. A. H. (2012). Kompetensi Pengadilan Agama Terhadap Penyelesaian Sengketa Perbankan Syariah Berdasarkan Hukum Islam. Sasi, 18(1), 56-62.

[6] Muskibah, M. (2011). Tanggung Jawab Sosial Perusahaan dalam Kegiatan Penanaman

$$
\text { 514|SASI Vo1. } 27 \text { No.4, Oktober - Desember } 2021
$$


Modal. Inovatif: Jurnal Ilmu Hukum, 4(5), 155-167. https://onlinejournal.unja.ac.id/jimih/article/view/542

[7] Nofrianto, N., \& Suardi, S. (2015). Bank Syariah Dan Pemberdayaan Coorporate Social Responsibility. Akademika: Jurnal Pemikiran Islam; Vol 20 No 2 (2015): Islam Dan Kesejahteraan Sosial. journal.metrouniv.ac.id/index.php/akademika/article/view/446

https://e-

[8] Nurhikmah, F., Winarsih, W., \& Kusumaningtyas, M. (2018). Pengaruh Dewan Pengawas Syariah dan Intelectual Capital Terhadap Pengungkapan Corporate Social Responsibility dengan Kinerja Keuangan Sebagai Variabel Mediasi (Studi Empiris Perbankan Syariah di Indonesia). MALIA: Journal of Islamic Banking and Finance, 2(2), 174. DOI : 10.21043/malia.v2i2.4785

[9] Pertiwi, D. (2019). Peran Dewan Pengawas Syariah (DPS) dalam Mewujudkan Good Corporate Governance di Bank Syariah. Jurnal Baabu Al-Ilmi: Ekonomi Dan Perbankan Syariah, 4(1), 1. DOI : 10.29300/ba.v4i1.1626

[10] Rahayu, R. S., \& Cahyati, A. D. (2014). Faktor-Faktor Yang Mempengaruhi Pengungkapan Corporate Social Responsibility (CSR) Pada Perbankan Syariah. JRAK: Jurnal Riset Akuntansi \& Komputerisasi Akuntansi, 5(2). DOI : 10.33558/jrak.v5i2.1346

[11] Syukron, A. (2015). CSR dalam perspektif islam dan perbankan syariah. Economic: Jurnal Ekonomi Dan Hukum Islam, 5(1), 1-22.

[12] Witasari, A. (2016). Perspektif Teori Kewenangan Dewan Pengawas Syariah (Dps) Dalam Rangka Penegakkan Prinsip-Prinsip Syariah Pada Lembaga Perbankan Syariah. Jurnal Pembaharuan Hukum, 3(1).

[13]Zuliana, R., \& Aliamin, A. (2019). Pengaruh Dewan Pengawas Syariah, Intellectual Capital, Dan Corporate Social Responsibility Terhadap Kinerja Bank Syariah Di Indonesia. Jurnal Ilmiah Mahasiswa Ekonomi Akuntansi, 4(4), 677-693. DOI : 10.24815/jimeka.v4i4.15335

[14]Zumaroh, Z., \& Wahyuni, D. (2019). Problematika Implementatif Corporate Social Responsibility (Csr) Pada Bank Syariah Di Indonesia. Jurnal Ilmiah Mizani: Wacana Hukum, Ekonomi, Dan Keagamaan, 6(2), 93-104.

\section{Buku}

[15] Marzuki, P. M. (2016). Penelitian Hukum. Jakarta : Kencana Prenadamedia Group.

[16]Firdaus, M. (2005). Briefcase Book Eduksi Profesional Syariah. Jakarta : Renaisan.

[17]Firdaus, M. (2007). Sistem dan Mekanisme Pengawasan Syariah. Jakarta : Renaisan.

[18] Hasanudin. (2002). Fungsi, Peran dan Mekanisme kerja Dewan Syari'ah Nasional MUI.

[19] Indonesia, T. P. P. S. I. B. (2002). Konsep, Produk dan Implementasi Operasional Bank Syari'ah. Jakarta : Djambatan.

[20]Labetubun, M. A. H. (2020). Pengaturan Perbankan Syariah Di Indonesia. In Pengantar Perbankan Syariah (pp. 103-117). Bandung: Widina Bhakti Persada Bandung.

[21] Nonet, \& Selznick. (2003). Hukum Responsif. Bandung : Nusa Media.

[22] Perwataatmadja, K., \& Antonio, M. S. (1992). Apa dan bagaimana bank Islam. Yogyakarta: Dana Bhakti Wakaf.

[23]Untung, H. B. (2008). Corporate Social Responsibility. Jakarta : Sinar Grafika.

[24] Wibowo, M. G. (2007). Potret Perbankan Syariah Terkini: Kajian Kritis Perkembangan Perbankan Syariah Terkini. Yogyakarta : Biruni Press.

\section{Online/World Wide Web, Tesis dll}

[25] Indonesia, B. P. dan P. B. K. P. dan K. R. (2016). Kamus Besar Bahasa Indonesia (KBBI). https://kbbi.kemdikbud.go.id/.

[26] Setiawan, A. B. (2009). Kesehatan Finansial dan Kinerja Sosial Bank Umum Syariah di Indonesia. Universitas Paramadina. 